\title{
History of Digital Dating: "Computer-Balls" and Digital Pairing in Finland from the 1960s to the Present
}

\author{
Jaakko Suominen \\ Degree Program in Cultural Production and Landscape Studies \\ University of Turku, P.O. Box 124 \\ 28101 Pori, Finland \\ jaakko.suominen@utu.fi
}

\begin{abstract}
This paper focuses on the cultural history of digital matchmaking from a Finnish point of view. By using examples from the mainframe computer era, personal computer applications, as well as from the age of the Internet, the paper argues that three reasons, popularization of technology, modernization of conventional partner seeking practices and the scientification of intimate relationships, are constantly adapted and appropriated to the language of the newest media and computing technology.
\end{abstract}

Keywords: Computer-aided matchmaking, cultural history of computing, Finland, love, online dating, popular culture.

\section{Introduction}

Matti Kosola, who advertised "The Computer Ball" at the Student Art Exhibition in Finland in 1968, used the following words.

A computer is a necessary tool in conquering space. It helps us in many other ways too: why not also in business, which could be far more interesting than the dark side of the Moon? A standard ball normally consists of a homogenized group, where we are most likely to find a suitable companion. During the event, we only have time to get to know ten to twenty people quite superficially and the selection criteria we apply are ridiculous compared to the scientific methods. In a dim light we - us men - carry out our selection on the basis of female appearance, or of the faces of those who are not on the dance floor at the time. And then, women have to choose between those ten to twenty male candidates who ask them to dance [1].

At the ball, the perfect dance partners were supposed to be selected with the help of a computer. Participants only had to fill in a form containing dozens of questions about their own personal features and qualities, state what their expectations of an ideal partner were - and then hope for the best from this "scientific method" [1].

"The Computer Ball," organized by the Student Union of the University of Technology in Espoo, Finland, was one example of the small boom in computer balls 
that, in all probability, followed American models. From today's perspective, those events appear as the pre-history of Internet dating services, and they certainly share some similarities. Computer-aided partner seeking has at least three different motives or themes: the popularization of technology, modernization of conventional partner seeking practices, and scientification of intimate relationships.

Love, emotions, and sensations are matters regularly used to introduce new computing technology [2-4]. This paper focuses on the cultural history of digital partner seeking from a Finnish perspective. By using examples from the mainframe computer era, personal computer applications, as well as from the age of the Internet, the paper argues that the three above-mentioned motives have been constantly adapted and appropriated to the language of the newest media and computing technology.

The paper is empirically based on interviews, archival material, cartoons, press clippings as well as films and TV-programs on digital dating. It is also related to the author's other studies on the cultural history of computing and popular media.

\section{Entertainment of Classification}

The American pioneer of punch card technology, Herman Hollerith used to travel on the railways at the end of the nineteenth century. Hollerith became acquainted with the system, which ensured conductors that a passenger's ticket was really the travel document of that particular passenger. He had seen how railway officers punched a "punch photograph" onto the ticket. This was a code, which, among other things, revealed the color of the eyes and hair - as well as the size of the passenger's nose.

At the same time, the population of the United States was increasing and the government was struggling with the Census, which it conducted every ten years. However, when the population grew rapidly, there was a risk that the task of calculating, listing, and tabulating would last more than ten years each time.

Hollerith won a contest, which sought a system that would speed up the computation. He had devised a method that was a kind of adaptation of the conductors' punch photographs, thereby generating punch card technology, which was successfully used since the 1890 Census [5].

Punch card machines - and computers thereafter - brought about the prospect of the statistical analysis of human characteristics. These developments led to different experimentations and applications, which were marketed commercially and popularized in different media. One particularly interesting topic was related to computer-aided matchmaking.

Rolf Strehl wrote in his book Die Roboter Sind Unter Uns, which was translated into Finnish in 1954, about "Machine Amor," a global business innovation and technology that American Clara Lane used for partner selection, by applying the "newest scientific principles of medicine, psychology and graphology." Candidates, seeking a spouse, also had to answer the most intimate questions, submit a handwriting sample, and do a drawing test. Strehl stated that the machine had brought about twenty thousand marriages, for judges, revue girls, teachers, opera singers, as well as for millionaires. Everything worked firmly and efficiently: "Robots provide quickly as lightning 'the absolute' partner for the customer, the partner who is the 
most suitable with his/her view of life, education, character, temperament, hobbies, orientations and cultivation" [6]. The computer accelerated the matchmaking as well as reduced the possibilities of "human errors" in choosing a suitable partner.

Although Strehl depicted the rationalization of matchmaking, the novel machinery was not only associated with the reasoning or scientification and technologization of aspects of human life. Popular media also eagerly introduced the new technology with humor and mysticism. The public seemed to become excited about the particular technological innovations and entertaining experiments that touched their emotional lives and mirrored the collective grand hopes, expectations, and threats of technologies.

From the 1950s onwards, the general public encountered computing technology, for the most part, through science fiction and popular media, which typically played with characteristics of machines, although developers wanted to emphasize the speed, rationality, and calculation abilities of computers and "electronic brains" [7, 4, 2]. Emotions and humor intermingled with work and efficiency in the Age of Automation. Computer-aided matchmaking, in this sense, titillated the public as well as the producers of new technology.

On 13 July 1957, a popular Finnish family magazine Apu ("Help") wrote about an American TV-show where couples find each other with the aid of a computer. The article popularized two essential technological innovations of that time, television and the computer. The journalist Lionel Crane described an episode of the People Are Funny TV-show where "The Love Robot" selected a man and a woman who suited each other perfectly, from over 2,500 candidates. The couple, Barbara Smith and John Caran, became quickly engaged: "It feels absolutely amazing that some sort of machine would have been able to define the tastes of both of us so infallibly like the robot did. After the first TV appearance I asked Barbara to have dinner with me - and then I proposed to her to marry me" [8]. In the story, the emotionless computer "knows" people; it is able to analyze details and can answer the specific questions posed.

\section{Computer at the Dance Halls}

Similar experiments and stories functioned as models for Finns when they conceived ideas about computer-aided dating during the 1960s. Moreover, Finnish cartoon makers and humorists had brainwaves on such occasions, devising comedy sketches about potential computer errors and the odds of too efficient computerized matchmaking. [9-16]

The first practical application took place within the Finnish dancehall culture, in the midst of the musical and economic changes of the 1960s. After the repeal of dance prohibition (which occurred during World War II), many new dance halls emerged and tried to compete by offering a choice of artists, as well as initiating all kinds of marketing campaigns [17]. Due to better roads and transport, the dancehall audience was more mobile than before, and sport clubs and other associations sought funding by organizing events during the short Finnish summer. Although huge events posed bigger risks, they could generate more funds. Dancehalls attracted people, and cultural geographer Pentti Yli-Jokipii notes, "dancehalls have been the essential stage 
for the matchmaking play in the Finnish summer" [18]. Soon they bought a computer to direct the arena of passion.

During the summers of 1966 and 1967, Mr. Kauko Lehtonen worked as "half a manager" of a dance pavilion that had been erected in Vehmassalmi, South West Finland, in 1963. As Lehtonen was strolling past the IBM computing centre in Turku, he remembered reading about American computerized matchmaking experiments at some exhibition. Lehtonen also decided to test the system with the help of the IBM centre [19], which was situated in a central place in Turku and had large display windows. People could therefore get together regularly to see the computer work [7].

"The Computer Ball" was also a way of promoting other balls organized in Vehmassalmi. Lehtonen portrays the process the following way:

The particular time was chosen to be at the beginning of June, the prime Midsummer period [when there would be a big festival with major artists]. The previous Saturday, every participant received a ticket on which they marked five characteristics of a desired partner. During the following week, the data was transferred to a computer. The machine analyzed the data and chose each participant's most suitable partner. The following Saturday everyone received a number on their chest and then found the partner with the same number in the audience [19].

\section{I Make Love with Pleasure - Students in Computer Dance}

After the Vehmassalmi experience, computer balls were also organized in the Helsinki area. Now the "scientific method" was portrayed as more advanced, and this scientification discourse legitimized the use of expensive computer technology for play and entertainment applications. One had to look for business in pleasure. This took place, when a computer ball was organized during the student art happening at Helsinki University of Technology (HUT) at the Espoo Dipoli in 1968.

The organizing team was not fully aware of the previous trial in Vehmassalmi and in a preliminary memo, the HUT organizers claimed that the computer ball was the first in Finland, which was quite typical rhetoric when introducing and popularizing new computing technology [1, 2, 7]. However, the Helsingin Sanomat newspaper returned the honour to Vehmassalmi and declared that the Vehmassalmi computer ball was the first in the whole of Europe. The newspaper did however state that the matchmaking by "the mechanical thinker" at the Dipoli was to be based on more substantial background research and material than before [20]. In addition, student psychologists, M.Soc.Sci Pekka Kansi and M.Soc.Sci Leif Sonkin, who had helped with the questionnaire, planned to write several academic papers based on the survey answers as well [21-24].

Students of technology, Ralf Saxén, Pieter Sigmudt, and Arno Wirzenius, were the fathers of the computer ball idea. As Lehtonen in Vehmassalmi, the trio got the idea from the American press. The students were responsible for mathematical planning as well as practical arrangements. In an interview, Saxén revealed that the software development was his and Sigmundt's practical work for technical physics and it was the most amusing laboratory work he had ever done in his studies. They also wanted 
maximum publicity for the recently completed Dipoli, a large and economically demanding building project for the Student Union of Helsinki University of Technology [25].

The organizers had managed to attract some sponsors for the event as well. IBM and the Computer Centre of the Finnish State helped to sort out the computer services and the major Nordic travel agency Spies provided a trip to Mallorca in Spain, as the lottery prize for the participants. Tillander promised to provide rings to the first couple to become engaged after the event. In addition, the couple most suited to each other, according to the computer, received a bottle of Italian sparkling wine. Therefore, the sale of the party tickets was marketed with the contemporary glamour ideals in mind, to which new technology added its own flavor. All these elements together created the promise of an experience that was exotic and imaginary, which hopefully was possible to achieve. The analysis of this popular cultural and technological utopian media field provides an opportunity to interpret a mixture of cultural values and ideologies attached to the phenomenon.

A total of seven hundred tickets were released for the festivity. In order to achieve an equal number of male and female participants, organizers not only marketed tickets to students of technology, but also to those at the Helsinki Schools (both Finnish and Swedish) of Economy, the University of Helsinki, the Nursing Academy as well as the Handicraft School [26].

Archival material does not reveal whether the event was a great success or not. However, according to Saxén, the occasion attracted wide media attention and was well received by the participants. At the start of the ball, participants searched for their partner, selected by the mainframe. This was followed by a dinner including wine to create a pleasant and relaxed atmosphere. The after party with dance was organized at the student union house and, according to Saxén, the ambience was eager and exciting. He estimates that two hundred of the seven hundred participants joined the after party, which was "one of the funniest" he had ever participated in. It transpired that the most suitable couple matched by the computer had actually dated before, but broken up. However, for a little while, their passions flared again due to the computer. The couple that won the trip to Mallorca pointed out later that the holiday was nice, but they did not continue dating. The morning after the party, two couples attempted to be the first ones to become engaged and obtain rings from Tillander [25].

The couple that happened to be the first was followed afterwards by the afternoon newspaper Ilta-Sanomat, which reported about their relationship a couple of times. However, they later broke their engagement. The organizers of the party were interviewed for several newspapers, magazines, radio, as well as television. A popular cartoonist Kari Suomalainen even drew a cartoon about the event: "What do you become when you are an adult? A computer pimp." Two firms contacted the organizers to obtain permission to use the application for their own parties (only one of them used it). Another student party was also organized, but it was not as popular as the first one. The organizers did not continue the computer dating experiments and one of the participant psychologists was even slightly worried about any erroneous impression of psychological work caused by the large media coverage of the event [25]. However, the popular and emotionally charged introduction of the computer matchmaking application did seem to be mostly successful. 
It is also fascinating to focus more carefully on the computer ball questionnaires, because they reveal the context of the partner seeking, the survey method, and student life of the 1960s. The survey forms (different ones for the male and female participants) comprised dozens of questions. The organizers explained the aim of the event as follows: "[P] their lives. Therefore, the main focus is on hobbies, outlook, and relation to sex life. Socio-economical background, which is one of the most important factors in a successful marriage, is mostly avoided" [1].

Respondents were asked to provide information about their attitudes to religion, alcohol, sex, gambling, fishing, animals, colors, comics, handcrafts, technical student humor, theatre, tobacco, politics, Ylioppilaslehti (a student newspaper), jazz, classical music, tennis, slalom or sailing (last three together), travelling, and dancing. They also had to comment on the following statements: "I make love with pleasure," "I am of the opinion that the woman should pay [food and drinks, etc.] herself," "I could accept living together without marriage." The questions appeared to relate to common values and sought answers about how students regarded other academic fields. As mentioned, the survey was based on an enjoyable evening, the primary aim of which was not necessarily marriage, as was the case with many other heterosexual matchmaking services [27].

The survey questions were understandable in the context of the 1960s and student life. At the time, according to historian Laura Kolbe, various student cultural activities were bound to tradition, just when the public discussion about relations between culture and society were increasing rapidly. Such discussions included debates on the value of modern art, popular culture, and so on. At the end of the decade, a rupture occurred and 1968 is known as "the mad year" of student radicalism. In Finland, students occupied the Old Student House in Helsinki [28].

\section{A Spouse for a Farmer?}

During the following decades, rationalization and popularization were repeatedly intermixed within computer-aided partner seeking. The Finnish TV program Napakymppi ("Bull's eye," 1985-2002) popularized the phenomenon, even though the role of the computer in deciding the most suited couple was not that explicit.

There was one other application that also received wide media attention without weekly television coverage: Leo Vimpari created the Choice of Man/Lady of the House (IEVA) application, which had its premiere at the Oulu agricultural exhibition in August 1982 and mainly targeted farm owners who were single. Just as in the previous cases, one had to fill in a form with the details of one's requirements. Vimpari explains the conditions of the service:

IEVA was created to cater for the needs of bachelor farmers. In many cases, low birth rates and risks that bachelor farmers posed for the continuity of life in the countryside had been noted. There were stories about villages where over half of the farms were occupied by bachelors ... So everything was about ... a farmer hoping to have some woman to share the life at the farm ... How to fix the situation? Modern technology in agriculture as well - a computer - that was it [29]. 
Again, it was a question of the rationalization of matchmaking with the help of modern technology. In this case, the matchmaking form comprised questions about wealth, hobbies, education, sociability, sobriety, and agricultural experience/ competence. The user could put more emphasis on certain aspects by using some important factors (as in online matchmaking services and in digital election machines later on).

IEVA was used at Farmers Exhibitions between 1982 and the 1990s. For example, by the end of 1986 almost 27,000 persons had participated. Vimpari argues that about 15 percent of participants filled in the form as a joke, but 85 percent were more or less serious about finding a partner. He also cites a study that claims that 8 percent of the participants had managed to find a partner-but not necessarily with the direct help of computers [29].

Fairs and exhibitions are good opportunities for the introduction and presentation of new technology, especially in cases where the fairs did not focus on technology itself. Fairs attract large crowds of people who want to see novelties and have fun together. IEVA received much exposure and interest on such occasions, people became accustomed to it, and they expected to see it at agricultural exhibitions.

IEVA was also featured in many newspaper and magazine articles, TV-programs, cartoons, and even in a fictional movie. The publicity was, according to Vimpari, very positive in general; he also received an award from the Society of Agricultural Journalists of Finland [29]. Likewise, in some 1960s cartoons, the publicity played with a combination of new technology, emotions, and rural culture. Behind this, there was concern about rural depression and the hope of creating a new life - literally, for the countryside, with the help of information technology. As an application, it consisted of many symbolic meanings connected to physical and mental reproduction.

\section{Online Matchmaking}

Matchmaking on the Internet partially differs from the previous examples.

Googling for love is not the last resort for a desperate single anymore. The Internet acts as a meeting forum for just ordinary people [30].

In this case, the computer not only calculates and suggests the best partners, but it also provides a possibility for the participants to communicate with each other. Net dating services started to flourish just after the popularization of the Internet in the mid1990s. Finnish Deitti.net ("Dates") started in 1995 and Sinkut.net ("Singles") in 1996. One reason for the popularization of these services, as well as the Internet in general, was the constant media attention in newspapers, magazines, TV-programs and the cinema. The first major net dating boom was connected internationally to the movie You've gotm@il (1998), which starred Meg Ryan and Tom Hanks. The movie, which also promoted the American Online Corporation, also encouraged discussion in Finland about the dangers and possibilities of net dating [31].

One can cautiously argue that in the last ten years online dating services have become simpler and more focused on serving the needs of different users and age groups. Currently, some of the services are free (obtaining income from advertising, etc.), but others are based on user fees. Moreover, nowadays, users must publish a 
recognizable photo on their profile page. In addition, a kind of online flirting and dating flourishes in different net environments such as Facebook and SecondLife, and not just on particular online dating services like match.com.

Today, the utilization of these services is no longer publicly presented as something odd, as in the past, but there is still a certain shamefulness linked to the use of the online dating application:

[Finnish Prime Minister Matti] Vanhanen and [Susan] Kuronen's love affair started to burn in early 2006. The relationship was revealed to the public in March. At first, the couple said that they met at Ikea, but they actually got together on the net, when Matti Vanhanen answered the dating advert of Susan Kuronen on Suomi24.fi-netportal. According to Kuronen, Matti Vanhanen wanted to keep the online dating secret; therefore she [or he] made up the Ikeastory ... After the break up, Susan revealed that the couple first met through the online dating services. In the interview for the Me Naiset magazine [Us Women] Susan said that Matti left her by announcing the fact in an SMSmessage [32].

\section{A Computer: The Emotional Problem Solver}

The previous examples illustrate that people have regularly harnessed technology to serve love and emotions. Typically, new information technology has acted as a solution for the difficulty of finding a partner-and sometimes for the trouble of breaking up with a partner. Often, the rationalization of the pair selection process is not the only goal. The application and services were also used to answer the needs of education, regional or national politics_or hegemonic scientific discourse. Even the resolutions were used to obtain wide public attention for new technology or certain values of the producers.

When popularizing science and technology, these aspects have been adjusted to the needs of everyday life and experiences. In addition, science and technology have been adapted to dominant economic and political objectives. They have been tuned to slowly altering ideas about emotions, love, human relations, sex and marriage, and finding Mr. or Mrs. Right.

\section{References}

1. Taidetapahtuma järjestää tietokonetanssit. Etukäteismuistio tai lehdistötiedoteluonnos [Art Happening organizes Computer Ball. A Preliminary Memo]. Polyteekkarimuseon arkisto, Otaniemi

2. Suominen, J.: Koneen kokemus. Tietoteknistyvä kulttuuri modernisoituvassa Suomessa 1920-luvulta 1970-luvulle [Experiences with machines. Computerised culture in the process of Finnish Modernisation from the 1920s to the 1970s]. Vastapaino, Tampere (2003) 
3. Suominen, J.: Computer as a Tool for Love - A Cultural History of Technology. In: Proceedings of 8th Annual IAS-STS Conference Critical Issues in Science and Technology Studies, CD-ROM. IAS-STS, Graz, May 4-5 (2009),

http://www.ifz.tugraz.at/index_en.php/filemanager/download/ 1558/Jaakko\%20Suominen.pdf

4. Suominen, J., Parikka, J.: Sublimated Attractions - The Introduction of Early Computers in Finland in the late 1950s as a Mediated Experience. Media History 16(3), 319-340 (2010)

5. Campbell-Kelly, M., Aspray, W.: Computer. A History of the Information Machine, pp. 20-26. BasicBooks, New York (1996)

6. Strehl, R.: Aikamme robotit. German origin Die Roboter Sind Unter Uns. Finnish translation O. E. Huhtamo. WSOY, Helsinki, pp. 195-196 (1954)

7. Suominen, J.: Sähköaivo sinuiksi, tietokone tutuksi. Tietotekniikan kulttuurihistoriaa [Getting familiar with the electric brain, getting to know the computer. A cultural history of information technology]. Jyväskylän yliopiston nykykulttuurin tutkimuskeskuksen julkaisuja 67. Jyväskylän yliopisto, Jyväskylä (2000)

8. Crane, L.: Uusin avioliiton välittäjä - koneaivot [The newest marriage arranger - machine brains] Apu (July 13,1957)

9. Alenius, S.: Reikäkorttien avioliitto" [Marriage of punch cards.] Apu 36 pp. 38-39 (1963)

10. Hurmerinta, O.: Tietokoneen tahdissa [In the pace of computer, a cartoon]. Apu 46, p. 18 (1963)

11. Hurmerinta, O.: Treffiautomaatti [A date automat]. Apu 37 p. 22 (1964)

12. Bygrave, H.: Kuinka hyvän vaimon tietokone valitsee [How good wife does a computer select]. Pirkka 3 pp. 26-27 (1967)

13. Introduction of the TV-programme Eddien isä (Eddie's father). Apu 5/, p. 131970 (in which episode aired on the A computer arranges a girlfriend for Eddie's father, but they don't really trust the possibilities of the machine (February 6, 1970)

14. I.S.: Vaarallista huvittelua: tietokoneella avioon [dangerous entertainment: to marriage with the help of computer]. Kymppi 8, 36-37 (1973)

15. Valitut Palat 12/, p.163 (1972) (an advertisement: "Oletko ylittänyt 40:n ja edelleen "yksinäinen susi". Tie ulos yksinäisyydestä on ehkä lyhyempi kuin luuletkaan. Jos etsit itsellesi elämäntoveria, Markus voi olla avuksi. Tietokonetekniikkaan ja arvostelukykyynsä nojaten Markuksen erikoistuntijat etsivät esille ihmisiä, joilla on hyvät edellytykset sopia yhteen kanssasi." [Are you over 40 and still a "lonely wolf". The road out of loneliness is shorter than you expect. If you seek a life partner, Markus can be of help for you. Experts of Markus based their knowledge on computing technology, and their own judgement and look for people who had good opportunities to get together with you]

16. Viki: Tietokoneiltamat [computer evening party]. Tekniikan Maailma 9, 98 (1968)

17. Pesola, S.: Kun suomalaiset äänestivät jaloillaan. Toisen maailmansodan tanssikiellosta tanssilavojen kukoistukseen. In. Terho, H. (ed.): Hetkiä historiassa. Cultural history kulttuurihistoria 2. Turun yliopisto, Turku (2002)

18. Yli-Jokipii, P.: Paikallisyhteisöjen muutos Suomessa kesäisten tanssilavojen kuvastamana. In: Löytönen, M. \& Kolbe, L.: Suomi. Maa, kansa, kulttuurit. SKS, Helsinki (1999)

19. Lehtonen, K.: Vehmassalmi muistoissani [Vehmassalmi in my memories]. Uudenkaupungin Sanomat (July 3, 2003)

20. Tietokonerakkautta taidetapahtumassa [Computer love in art happening] Helsingin Sanomat (March 8,1968) 
21. Taidetapahtuma järjestää tietokonetanssit [The art happening organizes computer ball]. Contactor, 3 (March 8,1968)

22. Otahuuto $7 / 1968$

23. Ylioppilaslehti (March 8, 1968)

24. Ylioppilaslehti (March 15,1968)

25. Saxen, R.: A phone interview by Jaakko Suominen (July 17, 2009)

26. Tietokonetanssilippujen jakelu. Muistio [Deliverance of Computer Ball Tickets. A Memo] Polyteekkarimuseon arkisto, Otaniemi

27. Tietokonetanssien kyselykaavakkeiden luonnokset [Outlines for survey forms of Computer Ball]. Polyteekkarimuseon arkisto, Otaniemi.

28. Kolbe, L.: Eliitti, traditio, murros. Helsingin yliopiston ylioppilaskunta 1960-1990. Otava, Helsinki (1996)

29. Vimpari, L.: Ieva ja muut puhemiehet. Oulu (1986)

30. Elomaa, J.: Nettideittailun @bc [@BC for Netdating] Ilta-Sanomat (December 9, 2006)

31. Turtiainen, R.: Tunne netissä. In: Saarikoski, P., Suominen, J., Turtiainen, R., Östman, S.: Funetista Facebookiin. Internetin Kulttuurihistoria [From Funet to Facebook. A Cultural History of the Internet]. Gaudeamus, Helsinki (2009)

32. Näin rakkaustarina eteni [So went the love story]. Ilta-Sanomat (February 20, 2007) 